DOI: 10.1515/jolace-2016-0010

\title{
Is relevance theory applicable to proverbs' translation?
}

\author{
Anca-Mariana Pegulescu \\ Romanian Ministry of Education and Scientific Research, Romania \\ a_pegulescu@yahoo.com
}

\begin{abstract}
Translation, viewed as a multi-faceted task, can arise different types of difficulties. Proverbs have been considered special patterns, displaying sometimes hidden meanings or suggesting morals issuing from a particular example. These paremic units - the proverbs - conveyed feelings, states of mind, behaviours or 'metaphorical descriptions of certain situations'(Krikmann). Starting from Savory's list of pair-wise contradictory translation principles, I intend to prove that the link between different 'forms' and their 'contents' lies in the principle of relevance when referring to proverbs. Even if relevance theory is not a theory of linguistic structure - and many translation problems imply structural mismatches - relevance theory offers insights about contextual information. Proverbs are seen as texts in themselves. My analysis will target the ethnofields of 'to buy' and 'to sell' in English proverbs and their Romanian corresponding versions.
\end{abstract}

\section{Keywords}

context, ethnofield, focal area, meaning, principle, structure.

\section{Towards a definition}

When uttering the word 'translation', we can think about:

- an abstract concept including both the process and the product, which means the activity of translating and translation as an entity;

- the translated text;

- the translator's method.

Among the theories that explained the term 'translation', the interpretive theory is focusing on the process, displaying domains belonging to psycholinguistics, semantics, pragmatics, cultural context, communication competence. From such a perspective, translation can be either an oriented text approach or an oriented interpretation analysis.

Roman Jakobson [1959:232-239] saw in the translation exercise three types of approaches:

- the intralingual translation;

- the interlingual translation which seems to be the translation in itself;

- the intersemiotics translation, where the non-verbal symbols can perform the interpretation of the verbal symbols.

Mounin saw in translation a series of operations whose final product bears in it the sum of meanings the translator can produce. Both Jakobson and Mounin considered translation an adequate interpretation of a unit which belongs to a different code than the one that is named the source text or the starting point in the translation exercise.

When a text is re-created through the translation exercise, the sender of the message has to cope with the addressee's register and at the same time the addressee has to understand the sender's language. It is called in translation terms a 'spiritual transfer'. Such a 'spiritual transfer' is almost the 
image of a 'perfect text'. The universal text is also very difficult to be obtained as it has to contain universal human values.

Romanian translators have been successful in both re-creating and conveying human values, as we do have nowadays what Mircea Eliade had as a dream that has become reality: a universal library offering world writers works, poets or playwrights translated in Romanian. There has been performed the version exercise as well: outstanding Romanian writers, poets or playwrights have been translated in different foreign languages, too.

\section{Is translation a pure interlingual and interpretive exercise?}

Target language readers do find themselves, sometimes, faced with contextual information that the source text authors understand differently. Such a situation can be explained either by the norms of structural organization that function in the two languages (viewed as 'source' and 'target') according to each specific linguistic system or the semantic mechanism that implies vocabulary choice and discourse analysis.

Many researchers suggest the possibility of an 'interpretive use across language boundaries' in the case of translation (Gutt, 2000).

English and Romanian do not belong to the same language family. Still, they have French as a common 'denominator'. French and Romanian belong to the romance languages family and on the other hand French has considerably influenced English in its whole linguistic system developed along the centuries (the most undeniable proof is the English vocabulary that has $40 \%$ words of French origin $-\mathrm{a}$ natural consequence of three centuries during which French was the administrative official language for the English kingdom born after the Norman Conquest in 1066).

Within the translation process, proverbs, seen as phraseological units or better said, independent texts, seem to be subjected to different types of reorganizations, transformations or modifications.

There are, however, proverbs that illustrate the perfect transfer from the source language (SL) to the target language $(\mathrm{TL})^{1}$ :

E: Better buy than borrow.

R: Mai bine cumperi decât să împrumuţi.

The above example is what we can call 'word-for-word' translation, the two languages displaying a pattern that involves the following structure: Adv. - Verb (comparison particle)- Verb.

\section{Method and corpus}

Due to the fact that translation is considered a multi-faceted task, my analysis, centered on the English and Romanian proverbs structure, will represent a combination of approaches among which I mention the relevance theory and the discourse analysis.

Within the corpus I selected, I have searched for:

- exact vs derived information:

E: Don't sell the bearskin before you killed the bear.

$R$ : Nu vinde pielea ursului din pădure.

(the first parts of the two paremic units are identical as pattern and meaning, while for the second part English retains the moment of killing the animal and the Romanian version focuses on the place' the animal lives in - the forest/ 'din pădure')

\footnotetext{
${ }^{1}$ My approach is a comparative one, implying the differences in patterns of cohesion of either English(SL) and Romanian(TL) proverbs or Romanian(SL) and English(TL) proverbs, within two ethnofields: 'to buy' and 'to sell' and respectively 'a cumpăra' vs 'a vinde'.
} 
- optimal relevance:

E; If you buy the cow, take the tail into the bargain.

R:Când te apuci de o treabă, n-o lăsa fără ispravă.

The transfer from the SL to the TL, in the above example is performed through what we can call 'indirect translation', fostering a personal apprehension of the message: English values the act of 'buying' which implies negotiation and the checking of the 'bought' object - be it [+animate] or [animate]. The animal which is taken as the example of the buying act - the cow - is usually valued for the milk and the meat. The source text author implies that 'the tail' is also important and he does oblige the ddressee of the message to think about all the elements that are necessary for a successful acquisition. The Romanian version of the English above mentioned proverb underlines another aspect: the importance of bringing to a good end a good beginning.

- a presumption of optimal resemblance:

E: The buyer needs a hundred eyes, the seller but one.

R: Mușteriul trebuie să se uite de zece ori, negustorul doar o dată.

There are, obviously, different attitudes and ideas concerning proverbs and the result of the translation process in proverbs. The majority of comparative works conclude on the difficulty of rendering the meaning as a whole in ready-made clichés. That is why changes - during the transfer from SL text to TL text - may occur under the form of possible:

- contamination:

R: Economul bun îşi cumpără iarna car şi vara sanie.

E: Have not thy cloak to make when it begings to rain.

(the wise man is both the person who buys cheaper needed objects during seasons when they are on sale and the one who has his clothes made before the cold weather begins)

- enlargement:

R: Să cumperi vecinii întâi şi apoi casa.

E:You must ask your neighbour if you shall live in peace.

(the neighbours are to be asked if the buyer of the house can live peacefully)

- reduction:

R: Nu cumpăra mâţa-n sac/ pisica-n traistă.

E: To buy a pig in a poke.

(from a SL negative sentence where the cat is in a sack, the TL retains a cliché, underlining the danger of buying something without seeing it)

The corpus extracted from Lefter's "Dicționar de proverbe, Englez-Român și Român-Englez” (2007), having the ethnofields of 'to buy' and 'to sell' as well as their Romanian versions, made possible an accurate analysis through the relevance theory mechanism and concepts, especially 'the degree of relevance' and 'the contextual effect'.

\section{Direct/ indirect translation vs the relevance theory}

The idea of the complete resemblance between the source language utterance/text and the target language utterance/text seems to be a possible definition of the direct translation:

E: Better buy than borrow.

R: Mai bine să cumperi decât să împrumuți. (translation) 
The above example excludes the explication of implicit information or changes in language. The idea of 'property' is universally desired and this might be the success of this direct translation example. The linguistic and the cultural differences seem to be annuled.

The question that may arise is whether the translator understands the cognitive environment accurately or not? The main advantage offered by a direct translation is that it provides the frame of reference for its own evaluation.

In indirect translation there is the translator's presumption that his interpretation adequately resemblances the original text in respects relevant to the target language text.

According to Zhonggang (2006, p. 47), the difference between direct and indirect translation is to be found in the degree of 'complete interpretive resemblance' vs 'the adequate resemblance in relevant respects' of the transfer from the source language text to the target language trext. Zhonggang's hypothesis is that translation is a clues based interpretive use of languages across languages boundaries.

Translation validity vs translation fidelity can be seen in what Roman Jakobson named in 1959 'equivalence'. During the 21st century very many other voices pleaded for the importance of communication, of the translator's intention(s) and the source text functions. Admitting that translation is an interlingual interpretive process means, in fact, that we can see in translation 'an act of ostensiveinferential interlingual interpretation of the source text (Zhao, 1999, cited by Zhonggang, 2006):

E1: He that buys land, buys many stones.

E2: He that buys flash, buys many bones.

E3: He that buys eggs buys many shells, but he that buys good ale buys nothing else.

R: Cine cumpără pământ, se-alege cu pietre, cine cumpără carne rămâne cu oasele,

cine târguiește ouă are parte de coji, dar cel ce cumpără bere bună, acela n-are ce

pierde. (trad.)

The above example shows that the translation exercise can be conducted via pragmatic-semantic strata of the text to be translated. The translator took into account the linguistic and the contextual difference between the source text and the target text. The direct translation was possible up to a point. The English proverb displayed three parts of the buying act, when any person who buys 'land' finds 'stones' or 'bones' after buying 'flash' or 'shells' after buying 'eggs'. The last part which can be seen as a conclusion is different in the English proverb as compared to the Romanian translation. For the English source text reader buying 'ale' means buying 'ale' and nothing else. For the target source reader (a Romanian one) the person who buys 'ale' has 'nothing to lose'. The contextual difference here is a matter of cultural awareness and clues-based interpretive exercise, a step towards relevance theory.

\section{Principles, rules and exceptions}

If we are tempted to believe Savory's rather negative evaluation of translation principles - there are no universally accepted principles of translation - then, we can believe that different readings of the same text may appear as distinct strategies for obtaining the most appropriate meaning.

Savory's 'pair-wise' contradictory translation principles rotate themselves around modal verbs like 'must', 'should', 'may' and hide, in a way, the importance of the main verbs like ,'read', 'reflect', 'possess', 'add', 'omit' or 'be'. The 12 principles are well known and my intention is not to analyse them but to underline the importance of a possible shift from the descriptive- classificatory aproach to an open explanatory one.

Proverbs, with their unique status of both literary and philosophical texts in themselves, can illustrate the hypothesis according to which translation is a clues-based interpretive use of language across language boundaries. They address themselves to individual source text readers/speakers as well as to collective ones, whose cognitive environment may be different from that of any other. Still, 
what really makes proverbs universal, is the metarepresentational use of the utterance and topics/themes they convey.

When referring to explicit vs implicit interpretive translation exercise, there can be a lower order of representation lying, in the resemblance of the communicative clues, while the truthfulness of the state of affairs may appear as a background image. According to Zhonggang (2006, p. 43-60), citing Gutt, the higher-order representation includes the intuition of the communication as well as the communicative clues inthe text. Translation, considered as a part of cross-culture communication is a higher-order communication, embracing the lower-order communication:

R: Cine deschide ochii după ce cumpără, cumpără totdeauna marfă proastă.

E1: The buyer needs a hundred eyes, the seller but one.

E2: Measure thrice what you buyest and cut it once.

The above example, which in the source language text - Romanian - displays a general universal relative pronoun 'cine' [who] as a starting point of the utterance, continues in the i-mode (based on the meaning intention), 'deschide ochii după ce cumpără' and develops the c-mode (based on the communicative clue of the verb 'a cumpăra', 'cumpără totdeauna marfă proastă'). A word-for- word translation of the Romanian proverb would give: 'who opens the eyes after having bought, always buys bad merchandise'. The first English version of the Romanian proverb I am analyzing has given 'The buyer needs a hundred eyes, the seller but one', emerging in the c-mode, as it gives the communicative clues 'buyer' vs 'seller' and infers the intention of the original communication: a buyer has to be very careful/attentive, looking at he/she wants to buy as having a hundred eyes, the seller does not need to be very attentive. The second English version as well as the first one implies 'the object/merchandise', without naming it as such. The idea of 'carefulness' remains. The 'buyer' (named in the first English version but absent in the second English version and contained only in the verb 'to measure') has to be attentive before buying, and more than that he/she has to 'measure' before 'cutting'. The implicit 'object' does not exist in the English text surface structure (though it does exist in the Romanian surface structure, the transfer from the source language text - Romanian - to the target language text - Englishbeing performed through an omission). The communicative clues 'buyer' and ' seller' make the inferential combination 'buy' - ' the buyer' vs 'sell' - 'seller' opposed to the verb 'to measure', building the context and recovering the information of the Romanian source degree text - ' the bad marchandise'. The second English version adds to 'the total communication intended or assumed by the writer (Larson, 1984) the importance of a 'wise, buyer who needs to measure carefully before cutting the 'merchandise'

The text vs the context opposition is to be found in the causal interaction between the two entities. The translator aim is to 'maintain a successful communication, irrespective of cultural and linguistic barriers, achieving an interpretive resemblance of the two texts. The context role is therefore very important if we think about the degree up to which the target language text is relevant to the target language reader/receptor/hearer and faithful to the source text reader.

Going back to the example I have chosen:

R: Cine deschide ochii după ce cumpără, cumpără totdeauna marfă proastă. (source language text-SLT1)

E1: The buyer needs a hundred eyes, the seller but one. (target language text -TLT2)

E2: Measure thrice what you buyest, and cut it but once.

(target language text -TLT3) 
the translator task has been to make the strata of T1 (the phonetic units, the semantic units, the schematized aspect units as well as the objective portrayed units)[Ingarden:1073] equivalent to the source language versions of the English text.

The translator of the Romanian proverb succeeded, in my opinion, to make sure that the target language texts both T2 and T3 resemble the source language text adequately. The four stratified structures of T1 met the causal interaction of T2 and T3. Regarding the meaning, T1 needed no significant change when the target language text $\mathrm{T} 2$ emphasized the role of the ' buyer':

\section{E1: The buyer needs a hundred eyes.}

as opposed to:

R: Cine deschide ochii după ce cumpără...

[Who opens the eyes after buying...]

Relevance as a comparative notion is different in degree if we discuss the second English version T3- of the Romanian proverb. In T3 - Measure thrice what you buyest, and cut it but once, the key word is 'buyest'. There is here, however, a modifying pattern of resemblance of the target language text meaning. The main emphasis in T3 is on 'measuring' and 'cutting' which can bring the implicit information of a possible 'tailor' who could have bought the 'merchandise'. It is very true that what Lakoff (1991) called 'possible factors' that can influence the language behavior (like class, gender, occupation) may bring some light within the text-context relationship in the case of T3.

\section{Conclusion}

There is no doubt that translation and the theory of relevance can work together in terms of processing efforts and contextual effects in the case of proverbs. From the undertaken analysis of the ethnofields 'to buy' and 'to sell' in English proverbs and their Romanian versions 'a cumpăra' and 'a vinde' it is very obvious that the translator of the source language text had to take into account the addressee's competence and the information that is given. The information can be a 'comprehensible input' in Krashen' terms or can be implicit.

Proverbs translation can be compared to literary texts translation. There is, nevertheless, a specificity that cannot be denied or ignored. A proverb as a source language text may represent a starting point. The target language text can contain words that correspond to the source language text, with regard to their function. In proverbs translation, one can also find:

- a words game;

- words that rhyme, referring to different targets;

R: Cine nu te știe, te vinde, iar cine te știe, te cumpără.

E: He who doesn't know you sells you, he who knows you, buys you.

I can affirm that relevance theory is applicable to translation and to proverbs' translation, too. Relevance can be optimal or even strong if the translation is a direct one. The weak relevance appears if the target language text changes the source text strata or even the meaning:

R:Inima de vânzător e venin otrăvitor.

E: In the heart of a traitor there is the most venomous poison (translation).

(the Romanian word 'vânzător' corresponds to both the English words 'seller' and 'traitor') 
On the other hand, as translation is a complex process, I cannot deny the importance of subjective thinking, even when we deal with small texts as proverbs. The Romanian source text can pick up a certain term while the English version chooses another. In the following example even if we deal with the wild animals' world, the difference between the 'actors' is a huge one:

R: Nu vinde pielea vulpii înainte de a o prinde.

E: Don't sell the bear's/lion's skin before you killed the bear/lion.

(Romanian prefers 'the fox' to the 'bear/lion' and Romanian does not kill the fox, it caches it)

In everything that displays the proverbs' implicit information, we can deal with the source text author's competence vs the target text reader's/hearer's competence. The context is important even if proverbs appear as texts in themselves.

\section{References}

GUTT, E.-A. (2000). Translation and relevance. Cognition and context. Manchester St. Jerome.

INGARDEN, R. (1973). The cognition of literary work of art. Evanston: Northwestern University Press.

LARSON, M. I. (1984). Meaning-based translation. A guide to cross-language equivalence. New York: UPA. ZHONGGANG, S. (2006). A Relevance Theory Perspective on Translating the Implicit Information In

Literary Texts. Journal of Translation, 2(2), 43-60.

\section{Contact}

Anca-Mariana Pegulescu, PhD

Inspector general for English, Japanese and Chinese

Romanian Ministry of Education and Scientific Research

28-30, G-ral Berthelot St.

București

România

a_pegulescu@yahoo.com 


\section{Appendices}

\section{To Buy \& To Sell}

1. Better buy than borrow.

Mai bine să cumperi decât să împrumuți. (trans.)

2. If you buy a cow, take the tail into the bargain.

Când te apuci de o treabă n-o lăsa fără ispravă.

3. The buyer needs a hundred eyes, the seller but one.

Mușteriul trebuie să se uite de zece ori, negustorul doar o dată.

4. He that buys land buys many stones; he that buys flesh buys many bones;

he that buys eggs buys many shells; but he that buys good ale buys nothing else.

Cine cumpără pământ, se-alege cu pietre,cine cumpără carne rămâne cu oasel, cine tărguiește ouă are parte de coji, dar cel ce cumpără bere bună, acela n-are ce pierde. (trad.)

5. Don't sell the bearskin before you killed the bear.

$\mathrm{Nu}$ vinde pielea ursului din pădure.

6. Ale sellers should not be tale -tellers.

Cârciumarul care știe toate ale mușteriilor săi, nu trebuie să bată toba.

7. Buy the truth and do not sell it....wisdom, instruction and insight as well.

Get the truth and never sell it; also get wisdom, discipline and good judgement/wisdom, instruction and understanding.

Cumpără adevărul și nu-l vinde....ințelepciune, educație și viziune.

Obține adevărul și nu-l vinde...obține și înțelepciune și bună judecată.

\section{A CUMPĂRA}

1. Cine deschide ochii după ce cumpără, cumpără totdeauna marfă proastă.

The buyer needs a hundred eyes, the seller but one.

Measure thrice what you buyest and cut it but once.

2. Cine nu te știe, te vinde, iar cine te știe, te cumpără.

He who doesn't know you, sells you, he who knows you, buys you.(trad.)

3. Economul bun își cumpără iarna car și vara sanie..

Have not thy cloak to make when it begins to rain.

4. Nu cumpăra mâța-n sac/pisica-n traistă.

To buy a pig in a poke.

5. Omul cuminte/gospodar își cumpără vara sanie și iarna car.

In fair weather prepare for foul.

He is wise that is ware in time.

6. Să cumperi vecinii întâi și apoi casa. 
You must ask your neighbour if you shall live in peace.

7. Săracul cumpără scump.

The poor man's shilling is but a penny.

8. Calul bun se vinde din grajd.

Calul bun din grajd se vinde; și mai bun preț pe el prinde.

Good ware makes quick markets.

9. La grădinar castraveți să nu vinzi.

An old fox needs learn no craft.

10. Nu se vinde gogoșarului, gogoși.

You must not teach fish to swim.

11. Nu vinde pielea vulpii înainte de a o prinde.

Don't sell the bear's /lion's skin before you killed the bear/lion.

12. Inima de vânzător e venin otrăvitor.

In the heart of a traitor there is the most venomous poison.(trad.)

13. Cu bani nu poți cumpăra fericirea, dar poți s-o închiriezi.

Money does not buy hapiness but you may rent it.

14. Banii nu aduc învățătură, dar învățătura adduce bani. 